\title{
The Redescription of the Full Coverage of “Lawyer's Defense" in Criminal Cases
}

\author{
Hong Yang \\ School of Politics and Law, Sichuan University of Arts and Sciences, Dazhou, China \\ Email: wknyh@163.com
}

How to cite this paper: Yang, H. (2020). The Redescription of the Full Coverage of "Lawyer's Defense" in Criminal Cases. Open Journal of Social Sciences, 8, 234-243. https://doi.org/10.4236/jss.2020.811022

Received: November 2, 2020

Accepted: November 21, 2020

Published: November 24, 2020

Copyright $\odot 2020$ by author(s) and Scientific Research Publishing Inc. This work is licensed under the Creative Commons Attribution International License (CC BY 4.0).

http://creativecommons.org/licenses/by/4.0/

\begin{abstract}
In October 2017, since China has implemented full coverage of lawyers' defense in criminal cases on a pilot basis in eight provinces and cities, the term for full coverage of lawyer defense in criminal cases has become a high-frequency word. However, if carefully studying the two paths proposed by the Chinese Supreme People's court, one would find that the full coverage of lawyer's defense in criminal cases is not real "full coverage of lawyer's defense", because the "legal assistance" of lawyers on duty is not "lawyer's defense". Restricted by the number of lawyers and the growth limit of the financial input in criminal legal aid, and considering the applicable conditions and the court trial mode of the rapid judgment procedure, China has neither the conditions nor the necessity to implement the full coverage of "lawyer defense" in the trial stage. So we should replace "full coverage of lawyers' defense" with "full coverage of legal aid".
\end{abstract}

\section{Keywords}

Lawyer's Defense, Legal Assistance, Not Worthy of the Name, Full Coverage of Legal Aid

\section{Introduction}

In 2014, the Fourth Plenary Session of the $18^{\text {th }}$ CPC Central Committee adopted the "Decision of the CPC Central Committee on several major issues of comprehensively promoting the rule of law", which clearly put forward the reform of criminal procedure system with "trial as the center". In order to coordinate with the decision-making and deployment of the CPC Central Committee, the Supreme People's court and the Ministry of Justice jointly issued "the measures for the pilot work of full coverage of lawyers' defense in criminal cases" (hereinafter referred to as "the Pilot Measures") in October 2017, which is determined to be pilot in eight provinces and municipalities directly under the Central Govern- 
ment. In January 2019, the Supreme People's court and the Ministry of Justice once again jointly issued the "notice on expanding the scope of trials for full coverage of lawyers' defense in criminal cases", from that time on, it has expanded the pilot scope to the whole country. Since the pilot project of full coverage of criminal defense, it has attracted the attention of legal and practical circles. Professor Fan Chongyi believes that "this is a major breakthrough in the history of China's defense, and it is a historic progress with the significance of the times (Fan, 2017b); Professor Chen Guangzhong proposed the "two-step" approach (Chen \& Zhang, 2018); Professor Gu Yongzhong also suggests two steps ( $\mathrm{Gu}, 2017)$, but the specific strategies are different. On the whole, it affirms the main significance of full coverage of lawyers' defense to protect the right of defense, but generally speaking, they hold a cautious attitude towards the promotion of full coverage of lawyers' defense.

The overall plan of the "Pilot Measures" for the full coverage of lawyers' defense in criminal cases is as follows: 1) The applicable stage of criminal procedure is limited to trial stage and does not involve pretrial procedure. 2) The scope of the applicable trial procedure includes the first instance procedure, the second instance procedure and the trial supervision procedure. However, the death penalty review procedure is not included; this is directly related to the Supreme People's court's understanding that the death penalty review procedure is not a "trial procedure". 3) There are two ways to achieve full coverage: if the defendant, who does not entrust a defender and is not within the scope of assigned defense, will be tried by summary procedure and rapid judgment procedure, the lawyer on duty shall be appointed to provide legal assistance for him; while in other cases, the people's court shall notify the legal aid institution to appoint lawyers to defend them. In short, it is called "full coverage of lawyer's defense", but in fact it is "legal assistance" and "lawyer's defense" to achieve full coverage.

\section{The Relationship between "Legal Assistance" and "Lawyer's Defense"}

\section{1. "Legal Assistance" and "Legal Aid" in International Law}

Article 14 (4) of the United Nations "Convention on Civil and Political Rights" stipulates that the accused shall have the right of legal aid to defend. The specific contents of the provisions are as follows: to be tried in his presence, and to defend himself in person or through legal assistance of his own choosing; to be informed, if he dose not have legal assistance, of this right; and to have legal assistance assigned him, in any case where the interests of justice so require, and without payment by him in any such case if he does not have sufficient means to pay for it. From the content and logic of the Convention, the "legal assistance" here refers to the defender, but the emergence of the defender is either selected by the defendant himself or appointed by the state. The emphasis is that the defendant must have a defender and the right of exemption when the defendant is unable to pay. 
Article 6 of "the basic principles on the role of Lawyers" adopted by the eighth United Nations Congress on the prevention of crime and the treatment of offenders in 1990 states that any person without a lawyer has the right to an experienced and competent lawyer assigned to him according to the nature of the crime in order to obtain effective legal assistance. If he does not have sufficient strength to pay for such services, he may not pay. This provision is a sub clause of "special safeguard clause in criminal justice", with emphasis on the effective legal assistance and the gratuitous nature of the assistance of the suspect and defendant. However, effective legal assistance can not be achieved by lawyers on duty who only provide "preliminary and timely" legal assistance.

Some scholars believe that the "legal assistance" mentioned above is actually connected or inseparable from "legal aid" and "lawyer's defense" (Gu \& Li, 2017), but the author do not think so. According to Oxford Advanced Learner's English-Chinese Dictionary (8 Edition) published by the Commercial Press and Oxford University Press, assistance (formal) means help or support. From the English expressions of the two nouns, we can see that legal assistance and lawyer's defence are not the same reference. Britain, Japan, Canada and other countries have implemented the lawyer on duty program, the expression of "legal assistance" has a broader extension. It can cover the legal assistance of lawyers on duty and the criminal defense of defense lawyers, and make the provisions of the treaty more accurate. Of course, legal assistance and legal aid or legal help can be used in common in these two treaties.

Secondly, the analysis of legal assistance and lawyer's defense must be carried out from the perspective of China's criminal justice context and China's criminal procedure system.

\subsection{The Proposal of "Legal Assistance" in China}

The amendment of the criminal procedure law in 1996 confirmed for the first time that lawyers can intervene in the investigation stage, but lawyers do not have the identity of defenders and their status is not clear. Therefore, in the theory of procedure law, the lawyer who is hired by the suspect in the investigation stage is called "the lawyer who provides legal assistance for the suspect", thus the word "legal assistance" is generated. The term "legal assistance" first appeared in the article 4 of "the notice on measures for carrying out pilot work of rapid judgment procedure of criminal cases in some areas" jointly issued by the Supreme People's court, the Supreme People's procuratorate, the Ministry of public security and the Ministry of Justice in August 2014. The content of the article is as follows: to establish a legal aid lawyers on duty system; the legal aid institutions shall assign legal aid lawyers on duty in the people's courts and detention centers. When a criminal suspects or defendants apply for legal assistance, legal aid lawyers should be assigned to them. Since then, the term "legal assistance" has appeared in many legal documents, such as "measures on pilot work of leniency system of guilty plea and punishment in some areas" (2016), "guid- 
ing opinions on the application of leniency system of guilty plea" (2019) and "working measures of legal aid lawyers on duty" (hereinafter referred to as "working measures of lawyers on duty") in 2020, etc., and it was finally written into Article 36 of the 2018 Criminal Procedure Law Amendment. It is worth noting that in all legal documents, including the code of criminal procedure, the subject of the word "legal assistance" is the lawyer on duty, in other words, "legal assistance" in China's criminal law is a description of the nature of the legal service provided by the duty lawyer for the suspect and defendant in criminal proceedings, it has specific connotation and denotation. This has been confirmed again in the definition of duty lawyer in the "working measures of lawyers on duty". Although the "working measures of lawyers on duty" has transformed the lawyers on duty into a humanized defender, and the duties of lawyers on duty have been greatly expanded, however, the lawyers on duty are not defense lawyers and do not possess the most typical investigations and evidence collection, attending courts, and cross-examination, debate and other core rights that best reflect the value of the right of defense in any case. The author believes that it is accurate and scientific to characterize the legal services provided by the duty lawyers and the defense lawyers to suspects and defendants as "legal assistance" and "lawyer defense" respectively. Duty lawyer and defense lawyer have different litigation status in procedural law, they can not be confused.

\section{On Duty Lawyer's Legal Assistance Function in Trial Stage}

In the two paths designed by the Supreme People's court and the Ministry of Justice to implement the full coverage of lawyers' defense at the trial stage, for cases that are applied to the rapid judgment procedure and the simplified procedure, the lawyers on duty provide legal assistance to achieve the full coverage of lawyers' defense. This is what this article thinks does not live up to the name of "full coverage of lawyer's defense", so it is discussed here.

The reform of "taking trial as the center" is put forward as one of the measures of "promoting strict justice"; what the reform decision-makers pay attention to is the significance of the "trial centered" reform in promoting the specific goal of "fact finding in line with the objective truth" (Fan, 2017a). The conditions of applying the rapid judgment procedure include clear facts and sufficient evidence, this standard already meets the conviction standard of the people's court stipulated in the criminal procedure law. Therefore, the court investigation and court debate are generally not conducted, and the fact identification and evidence display are not carried out during court trials. The judge forms his inner confirmation that the defendant's behavior constitutes a crime by reading files before court session and the statement of guilty plea signed by the defendant, so the significance of the lawyer on duty and even the defender's participation is almost lost.

Since the initial motivation for the introduction of the lawyer on duty system is to cooperate with the pilot trial of the rapid judgement procedure and the le- 
niency system for confessing guilt and punishing, the academic circle mainly discusses the function of duty lawyer in pleading guilty and punishing cases. In China, the lawyers on duty mainly participate in pleading guilty and punishing cases during the review and prosecution stage of criminal case, so the discussion on the role of duty lawyer in the trial stage is mainly found in some papers in the field of practice. In Pudong District, Shanghai, the duty lawyer assigned to court is to provide legal advice, mainly to answer procedural and transactional issues related to litigation, and the work content is single and mainly focuses on civil consultation ( $\mathrm{Hu} \& \mathrm{Liu}, 2020$ ). In Hangzhou, if there is a case for which the summary and rapid judgment procedure is applicable, the lawyer on duty on the day notified by the judge shall provide a legal assistance (mainly consultation) for the defendant before the court session (Chen \& Dong, 2018). Shanghai and Hangzhou are very advanced cities in economic and social development in China, the role of lawyers on duty plays in the trial procedure is just like this, and other cities or regions need not be investigated.

Article 224 of China's criminal procedure law in 2018 stipulates that the application of the rapid judgment procedure in the trial of a case is not limited by the time limit of service stipulated in Section 1 of this chapter. Generally, no court investigation or court debate is conducted. However, before the judgment is announced, the opinions of the defender and the final statement of the defendant shall be heard. The code of law requires that the defendant must have a defender to assist him in exercising his right of defense. However, in judicial trial, the so-called legal assistance (mainly legal consultation) of lawyers on duty in a more simplified sense even can not be implemented. On the one hand, the conflict between legislation and legal documents has already existed. On the other hand, judicial practice has made the legal documents issued by the People's Supreme Court become ornaments. Under such circumstances, have we achieved "full coverage of lawyers' defense" in the trial stage? The answer is obviously No. In fact, we even have not realized the full coverage of legal aid in the trial stage.

As can be seen from the above, in the trial stage, as one of the ways to achieve full coverage, "legal assistance of lawyers on duty" has been shelved in judicial practice. There is no doubt that if we can guarantee that all the defendants have defenders at the trial stage, whether the defendants entrust themselves or the way the state provides legal aid, that is the most ideal state. However, at this stage in China, do we have the corresponding conditions? Under the current criminal procedure system, is it necessary to promote "full coverage of lawyers' defense"?

\section{Is It Necessary and Possible to Realize "Full Coverage of Lawyers' Defense" in Trial Stage?}

\subsection{Discussion on the Necessity of "Full Coverage of Lawyers' Defense"}

In recent ten years, the number of criminal cases in China has continued to show an upward trend. In 2012, the number of first instance criminal cases was 
986,392; and in 2019, it increased to 1.29 million. At the same time, the number of cases of second instance also continued to grow, reaching 151,753 cases in $2017^{1}$. From the statistical data, it is very difficult to realize the task of "full coverage of lawyers defense" only in the trial stage.

In December 2019, the application rate of leniency system of confession and punishment has reached $83.1 \%$ (Zhang, 2020). The cases that actually apply to the crime confession and punishment in the pilot process are mainly concentrated in light punishment cases, among which $96.2 \%$ of the penalty sentenced to less than three years of fixed-term imprisonment are given ${ }^{2}$. With the promulgation of the "guiding opinions on the application of leniency system of guilty plea" (2019) issued by the Supreme People's court, the incentive function of confession is clear, there will be more cases applying the leniency system of confession. Even in the case of felony, the proportion of applying lenient system of confession and punishment will increase. Taking the above four factors into consideration, it is conservatively estimated that the number of cases due to pleading guilty and punished and satisfy the applicable conditions of the rapid judgment procedure can reach about $40 \%$ of the total number of cases concluded in the first instance procedure, that is to say, about 520,000 cases (calculated based on the number of cases concluded in 2019) will be tried by rapid judgment procedure. Considering the applicable conditions of the rapid judgment procedure and the way the procedure is carried out (mentioned above), rather than the intervention of the defense lawyer, even the formal help of the lawyer on duty seems unnecessary.

\subsection{On the Possibility of Realizing "Full Coverage of Lawyers' Defense"}

In order to realize the full coverage of lawyer's defense in trial stage, we must find out the "family background" first, that is, whether the necessary conditions are met. Due to space limitations, the following discussion will mainly conducted from two aspects: human resources and financial resources.

\subsubsection{The Existing Size of Lawyers Can Not Support the "Full Coverage of Lawyers' Defense"}

To realize the full coverage of lawyer defense, it is necessary to have sufficient lawyer resources. According to "the statistical analysis of lawyers and grassroots legal services in 2019" released by the Ministry of Justice, there are more than 397,300 full-time lawyers, accounting for 84\%; more than 12,500 part-time lawyers, accounting for 2.66\%; in addition, there are about 55,700 public lawyers, company lawyers and military lawyers. Among the 6.018 million cases handled by lawyers, more than 1.094 million cases were defended and represented in

${ }^{1}$ Data from the 2013 and 2018 China Law Yearbook and the "work report of the Supreme People's court in 2019".

${ }^{2}$ See Zhouqiang: "interim report of the Supreme People's court and the Supreme People's Procuratorate on the pilot work on the leniency of the confession and punishment of criminal cases in some areas." 
criminal proceedings, accounting for $17.91 \%$ of the litigation cases. Through the above data, we can draw the following conclusions: 1) the total number of full-time and part-time social lawyers is about 410,$000 ; 2$ ) criminal defense is not the main business scope of the majority of lawyers. Professor Fan Chongyi, a famous scholar in the field of Criminal Procedure Law, once mentioned in his paper, at present (referring to 2017), China has 340,000 registered lawyers, of which 52,000 are criminal lawyers (Fan, 2017c). This data can be used as evidence to prove that the proportion of criminal defense lawyers in China is not high, only about $15.3 \%$. It is roughly equivalent to the $17.91 \%$ of criminal cases handled by lawyers mentioned above, which is credible. If calculated based on this ratio, the current criminal lawyers will not exceed 72,000. Although all lawyers can handle criminal cases theoretically, the quality of criminal defense relates to the realization degree of the suspect and defendant's right to defense. Obviously, those who regard the criminal defense business as fulfilling the legal obligation as well as "hobby" can not provide effective defense. As a result, the object of realizing the procedural pretrial realization, the right to defend and the prevention of miscarriage of justice become an empty talk. Even if all the social lawyers are involved in the criminal legal aid business, at other stages they still need to serve as duty-lawyers and designated defenders, as well as legal aid in civil and administrative cases, which will unbearable for lawyers all. Moreover, it is an indisputable fact that the deviation between the low standard of case subsidy and the profit seeking nature of the legal service market determines the low quality of criminal legal aid.

\subsubsection{The Limited Growth of Legal Aid Funds Can Not Meet the Huge Market Demand of Criminal Legal Aid}

The total amount of legal aid funds has been growing and increasing in China, such as 280 million 500 thousand in 2005, 1 billion 707 million in $2014^{3}$, while in 2018, it reached 2,651,070,800 yuan ${ }^{4}$. Although legal aid funds continue to increase, but the scope of legal aid in China has been expanding also, so the actual increase is not obvious. As a part of basic public services, legal aid funds are basically invested by the state finance, which is bound to be constrained by the overall financial capacity of the state and the structure of public services. As a developing country and not very wealthy, China is unlikely to increase legal aid funds substantially in the future. However, the vigorous criminal justice reform has spawned a greater demand for criminal legal aid, and the tension between the two is difficult to resolve.

Based on the total legal aid fund of 265.10708 million yuan in 2018, the total population of the mainland was 1395.38 million at that time in China, We can calculate that the legal aid fund per capita in 2018 is only about RMB 1.9. Com-

${ }^{3}$ The data are from Hu Ming and Wang Tingting, the Chinese mode of legal aid and its reform, Zhejiang University journal, 2017 second, 78.

${ }^{4}$ The data are from the development report of China's legal aid system No. 1 (2019) issued by the Chinese Academy of Social Sciences, which comes from the legal daily legal affairs website at 14:20, December 30, 2019, and the interview time is October 2, 2020. 
paring with 243.5 yuan per capita in 2014 in the United Kingdom (Wang, 2018), the gap is undoubtedly huge. Britain, which claims to be a "global leader" in the criminal legal aid system, has carried out the criminal legal aid reform agenda since 2012. The reason for the reform is "the urgent need of finance" (Mike \& Luke, 2018); its essence is to reduce the funds for legal aid. The pursuit of fairness and justice has to consider the cost. As a developed country, Britain still has the pressure of financial burden, let alone our country. In short, even in the trial stage, China's financial resources are not enough to support the full coverage of lawyers' defense.

In short, only from the perspective of the size of lawyers and legal aid funds, China does not have the basic conditions to promote the full coverage of real "lawyer defense" in the trial stage. In addition, in the current criminal procedure system, the design of quick judgment procedure and summary procedure makes lawyers' defense seem useless.

\section{Findings and analysis}

Since the Supreme People's Court promulgated the "Pilot Measures", although "full coverage of lawyers' defense" has become a high-frequency word in official documents, the author thinks that this usage is not accurate to use "full coverage of legal aid". Because in the context of China, combined with the current legal provisions, "lawyer's assistance" is not "lawyer's defense". Professor Chen Ruihua pointed out that "there are two basic modes of legal aid: designated defense and duty lawyer" (Chen, 2019). It can be seen from this that the mainstream view of China's academic circles is that the legal services provided by lawyers on duty belong to legal assistance rather than lawyers' defense.

Through the amendment of the criminal procedure law in 2018, the duty lawyer system has become an integral part of China's criminal legal aid system, but it is impossible for the duty lawyer to replace the defense lawyer. Even if the connotation of legal assistance may overlap with part of the functions of the defense lawyer, it is not impossible to replace it. The structure and the concept of criminal procedure determine that at the trial stage, we have neither financial resources nor enough criminal defense lawyers to provide defense services for each defendant, and there is no need to provide defense lawyers for all cases. The realization of justice must also weigh the country's financial burden, and it is irrational and unsustainable to do so at no cost. The legal assistance provided by lawyers on duty can satisfy the due process protection of the defense rights in some cases with a low-cost and wide-coverage method. How to implement the established promotion path is a top priority now, that is to implement the protection of the defendant's right to defense in the cases of applying the quick judgment procedure and the summary procedure, and to explore the ways, ways and time arrangement of the lawyers on duty to play the legal assistance function in these two procedures, so as to achieve the reformers' declaration of "reducing procedures but not reducing rights", and finally realizing the original intention of the reform of procedural justice and preventing unjust, false and wrong cases. It is a wise move to promote the full coverage of lawyers' defense when the con- 
ditions are met in the future.

\section{Conclusion}

In short, the full coverage of lawyers' defense in criminal cases currently proposed by our country is not worthy of its name; we should face the reality and change "full coverage of lawyer defense" to "full coverage of legal aid". The reform of litigation system with trial as the center must start with the substantiality of trial, and the realization of the substantiality of trial is bound to depend on the exertion of the defense function. Therefore, the judicial reform requires that the defense rate of lawyers be greatly increased. However, throughout the world, the improvement of the defense rate of criminal cases mainly depends on the legal supply of the state. China has realized the importance of criminal legal aid, but the current measures are too rash.

The statement of "full coverage of Legal aid" can not only meet the needs of the current criminal justice reform in China, but also have considerable inclusiveness, and it leaves room for the full implementation of legal aid throughout the whole criminal procedure in the future.

Although the reform on the full coverage of lawyer's defense in criminal cases is still in the pilot stage, the practice of expanding it to the national pilot and the experience of the pilot reform in the field of criminal justice in recent years show that this measure is likely to be eventually absorbed and confirmed by the code of criminal procedure. Based on this, we should make a pragmatic and prudent investigation on this system, follow the law of criminal justice, and construct this system scientifically and rationally, and strive to have a mature system and institutional guarantee when it is written into the criminal procedure code. Only in this way can we provide system support for the further practical and feasible protection of the defendant's right to defense, the realization of the substantive trial and the prevention of unjust, false and wrong cases.

The 40-year history of the development of the rule of law in criminal procedure has witnessed the fact that the level of protection of the right to defense in China has been continuously improved. But the reform decision-makers have not paid real attention to the reform of the defense system, and have not made substantive institutional innovation to the opportunities for the suspects and defendants to obtain effective defense (Chen, 2017). We still have a long way to go to protect and enhance the defense rights of the suspect and defendant.

\section{Fund Project}

2020 Project of Dazhou Social Science Federation of Sichuan Province "Research on full coverage of lawyer defense in criminal cases".

\section{Conflicts of Interest}

The author declares no conflicts of interest regarding the publication of this paper. 


\section{References}

Chen, G. Z., \& Zhang, Y. N. (2018). Discussion on Promoting the Full Coverage of Legal Aid for Criminal Defense. Law Journal, No. 3, 9.

Chen, K., \& Dong, H. M. (2018). Practice and Thinking on Full Coverage of Lawyer's Defense in Criminal Cases-Taking Hangzhou City as an Example. Justice of China, No. 11,41 .

Chen, R. H. (2017). Theoretical Reflection on the Reform of Judicial Centralism. Procedural Law and Judicial Systems, No. 7, 11.

Chen, R. H. (2019). Review and Prospect of Criminal Defense System in the Past 40 Years. Tribune of Political Science and Law, No. 6, 4-5.

Fan, C. M. (2017a). The Differences and Solutions of the Discourse System of Trial Centered Theory. Chinese Journal of Law, No. 5, 199.

Fan, C. Y. (2017b). Let Every Criminal Case Be Defended by a Lawyer. The People's Rule of Law, No. 11, 81.

Fan, C. Y. (2017c). Let Every Criminal Case Be Defended by a Lawyer. The People's Rule of Law, No. 11, 80.

Gu, Y. Z. (2017). On the Challenge and Realization Path of Full Coverage of Criminal Lawyer's Defense. Justice of China, No. 7, 25.

Gu, Y. Z., \& Li, X. Y. (2017). On the Proper Orientation of Duty Lawyers in China, Hunan. Journal of Hunan University of science and Technology (Social Science Edition), Vol. $20,81$.

Hu, X. W., \& Liu, W. L. (2020). An Empirical Study on the Work of Lawyers on Duty in Legal Aid-Take Pudong District of Shanghai as an Example. Justice of China, No. 4, 85.

Mike, M., \& Luke, M. (2018). Criminal Justice: Legitimacy, Courts and State-Induced Guilty Pleas in Britain, Translated by Fu Xin (pp. 295-296). The Commercial Press.

Wang, Y. L. (2018). On the Chinese Model of Criminal Legal Aid-The Realization Path of "Full Coverage of Lawyer's Defense in Criminal Case". Chinese Journal of Criminal Law, No. 2, 125.

Zhang, J. (2020). Work Report of the Supreme People's Procuratorate in 2020. 